\title{
The tadpole of Chiasmocleis carvalhoi and the advertisement calls of three species of Chiasmocleis (Anura, Microhylidae) from the Atlantic rainforest of southeastern Brazil
}

\author{
Henrique Wogel, Patrícia A. Abrunhosa, and Gustavo M. Prado \\ Setor de Herpetologia, Departamento de Vertebrados, Museu Nacional / UFRJ, Quinta da Boa Vista, São Cristóvão, \\ Rio de Janeiro, RJ, 20940-040, Brazil. E-mails: hwogel@acd.ufrj.br; abrunhos@acd.ufrj.br; gmprado@ig.com.br.
}

\begin{abstract}
The tadpole of Chiasmocleis carvalhoi and the advertisement calls of three species of Chiasmocleis (Anura, Microhylidae) from the Atlantic rainforest of southeastern Brazil. The tadpole of Chiasmocleis carvalhoi is figured and described for the first time from individuals collected in the State of Rio de Janeiro, southeastern Brazil. The advertisement calls of C. atlantica, C. capixaba, and C. carvalhoi also are described and compared with the advertisement calls of others Chiasmocleis species restricted to Atlantic Rainforest. The advertisement calls of $C$. atlantica, $C$. capixaba, and $C$. carvalhoi are similar, consisting of one pulsed note of harmonic structure emitted repetitively. Our study corroborates the monophyly of the genus Chiasmocleis based on similarities in advertisement calls. Calls of syntopic species (C. atlantica with $C$. carvalhoi and $C$. capixaba with $C$. schubarti) were less similar than those of closely related allopatric species.
\end{abstract}

Keywords: Anura, Microhylidae, Chiasmocleis atlantica, Chiasmocleis capixaba, Chiasmocleis carvalhoi, tadpole description, advertisement call, Atlantic rainforest, southeastern Brazil.

\section{Introduction}

As currently recognized, the Neotropical microhyline genus Chiasmocleis Méhelÿ, 1904 includes 18 species, distributed from Panama to southern South America, north and east of the Andes (Caramaschi and Cruz 2001, Caramaschi and Pimenta 2003, Frost 2003). Eight species are restricted to the Atlantic Rainforest: $C$.

Received 5 March 2004.

Accepted 18 November 2004.

Distributed December 2004. alagoana Cruz, Caramaschi, and Freire, 1999; C. atlantica Cruz, Caramaschi, and Izecksohn, 1997; C. capixaba Cruz, Caramaschi, and Izecksohn, 1997; C. carvalhoi Cruz, Caramaschi, and Izecksohn, 1997; C. cordeiroi Caramaschi and Pimenta, 2003; C. crucis Caramaschi and Pimenta, 2003; C. leucosticta (Boulenger, 1888), and C. schubarti Bokermann, 1952. Descriptions of male vocalizations are known for C. carvalhoi (Nelson 1973, Hartmann et al. 2002), C. leucosticta, and C. schubarti (Nelson 1973). Tadpoles have been described for only two species of Chiasmocleis 
(Chiasmocleis cf. shudikarensis and C. ventrimaculata, Hero 1990, Schlüter and Salas 1991). Furthermore, only the tadpole of $C$. ventrimaculata was described in detail (Schlüter and Salas 1991). Herein, we describe the tadpole of $C$. carvalhoi and the advertisement calls of $C$. atlantica, C. capixaba, and $C$. carvalhoi. In addition, we compare the advertisement calls among the Chiasmocleis species from the Atlantic Rainforest.

\section{Materials and Methods}

During a community study from February 2001 to January 2002, at Reserva Biológica de Duas Bocas $\left(20^{\circ} 16^{\prime} \mathrm{S}, 40^{\circ} 28^{\prime} \mathrm{W}\right.$; $200 \mathrm{~m}$ above sea level), Municipality of Cariacica, State of Espírito Santo, southeastern Brazil, we recorded advertisement calls of one male of Chiasmocleis capixaba in a temporary pond within the forest. Observations of breeding activities of $C$. atlantica and $C$. carvalhoi in a temporary pond of approximately $750 \mathrm{~m}^{2}$ also were made at the edge of a forest at Reserva Biológica União ( $\left.22^{\circ} 31^{\prime} \mathrm{S}, 41^{\circ} 56^{\prime} \mathrm{W}\right)$, Municipality of Rio das Ostras, State of Rio de Janeiro, southeastern Brazil. Fieldwork was conducted from September 2002 to May 2003 for a total of 48 nights. An amplectic pair of $C$. carvalhoi was kept in laboratory until oviposition. The tadpoles were reared and sequentially preserved in $5 \%$ formalin to provide a representative sampling of the developmental sequence. We also collected tadpoles in the natural habitat and compared them with those reared in laboratory. The description of the tadpoles was based on larval Stages 28, 30, 31, 33, 35, and 39 (Gosner 1960). Several stages were used to assess ontogenetic changes during development. Measurements were made on larvae at Gosner's Stage 35. The dental formula and measurements follow the guidelines provided by Altig (1970) and Altig and McDiarmid (1999), with exception of the interorbital and internostril distances, which was taken between the inner edges of the eyes and nostrils. We used an ocular micrometer with a Zeiss stereomicroscope to take all measurements to the nearest $0.1 \mathrm{~mm}$. The terminology describing the spiracle, anal tube, tail tip and oral apparatus follows that of Altig and McDiarmid (1999). Illustrations were prepared using a Zeiss stereomicroscope with a camera lucida. Voucher tadpoles of Chiasmocleis carvalhoi are deposited in Museu Nacional / UFRJ, State of Rio de Janeiro, Brazil (MNRJ 33772-33777).

Vocalizations of Chiasmocleis capixaba were recorded with an Aiwa TP-VS 480 recorder and a Le Son MK-60 microphone, and those of $C$. atlantica and $C$. carvalhoi were recorded with a Panasonic recorder, Model $\mathrm{N}^{\circ}$ RQ - L30. All vocalizations were digitized and edited at a sampling frequency of $22 \mathrm{kHz}, \mathrm{FFT}$ with 256 points, and 16-bit resolution, and analyzed with Avisoft-Sonagraph Light 1 (Version 2.7) and Cool Edit 2000. Vocalization terminology follows Duellman and Trueb (1986). A cluster analysis for the five rainforest species of Chiasmocleis ( $C$. atlantica, $C$. capixaba, C. carvalhoi, C. leucosticta, and $C$. schubarti) was performed based on call duration and dominant frequency. The Average Linkage Method (Euclidean distance) was employed to verify the similarities among advertisement calls of the individual species (Mainly 2000). Call data for C. leucosticta and C. schubarti were taken from Nelson (1973).

\section{Results}

\section{Description of the Tadpole of \\ Chiasmocleis carvalhoi}

The following description is based on an individual in Stage 35 (Figure 1). Overall body oval in lateral view and rectangular in dorsal and ventral views; body representing about $35 \%$ of total length; greatest body height in its posterior third; greatest body width immediately behind eyes; snout protruding in lateral view and truncate in dorsal and ventral views; eyes lateral, located on the anterior third of body; nostrils 
absent; spiracle single, median, posterior ventral; spiracle long, reaching or passing the opening of the anal tube, spiracle height at least half of the height of the anal tube (spiracle broad); anal tube medial, with opening directed downward, and attached directly to ventral fin; dorsal fin originating at the end of the body; fins approximately straight and parallel for first two-thirds tail; caudal tip flagellate; greatest caudal height found in anterior half of tail; oral disc terminal with paired, semicircular labial flaps suspended in front of the mouth and separated by an inverted, U-shaped medial notch (Figure 1D); jaw sheaths, papillae, and tooth rows absent. Morphometric data are in Table 1.

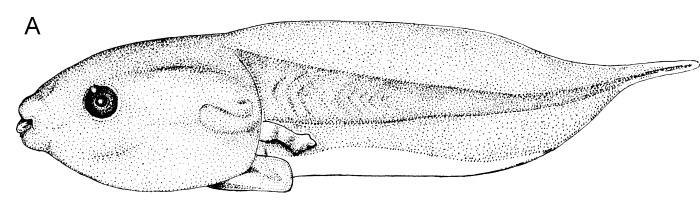

B

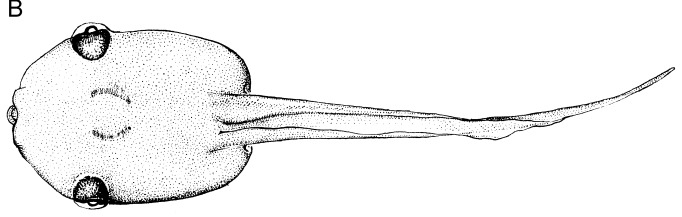

C
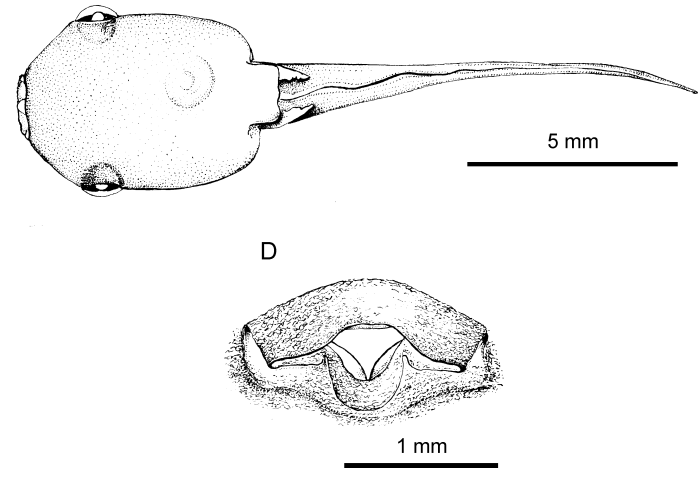

Figure 1. Tadpole of Chiasmocleis carvalhoi, Stage 35 (MNRJ 33772). (A) Lateral, (B) dorsal, (C) ventral views; (D) oral disc.

\section{Coloration}

In life, dorsum brown extending onto the lateral surface of body, somewhat below the median line of body; a pair of curved, bracketshaped, and light-cream lines between the eyes; tail musculature and fins light-brown; ventrally, belly translucent and without pigmentation, particularly on its anterior two thirds. In preservative, brown color pattern faint.

\section{Variation}

The spiracle morphology and the presence of bracket-shaped marks vary among developmental stages. We observed a total of 21 tadpoles, in addition to the one described above. In four (at Stages 28, 29, 30, and 31), the spiracle is short and narrow. Six $(\mathrm{N}=1$, Stage $30 ; \mathrm{N}=3$, Stage 31; $\mathrm{N}=1$, Stage 32; $\mathrm{N}=1$, Stage 35$)$ have long, narrow spiracles, and 11 tadpoles $(\mathrm{N}=1$, Stage $32 ; \mathrm{N}=1$, Stage $33 ; \mathrm{N}=$ 8 , Stage 35; $N=1$, Stage 39) have long, broad spiracles.

Bracket-shaped marks are not present between the eyes in five tadpoles $(\mathrm{N}=1$, Stage $28 ; \mathrm{N}=$ 3 , Stage 30; $N=1$, Stage 39); however, these marks are evident in 16 other individuals $(\mathrm{N}=4$, Stage 31; $N=3$, Stage 33; $N=9$, Stage 35).

\section{Vocalizations and Notes on Reproduction}

The advertisement calls of Chiasmocleis atlantica, C. capixaba, and C. carvalhoi are similar (Figures 2-4). They consist of one pulsed note that is emitted repetitively, and according to spectrogram (Figure 4), the calls possess harmonic structure. The call duration, number of pulses, pulse duration, and intervals between pulses of $C$. atlantica are greater than in $C$. capixaba and $C$. carvalhoi; the interval between notes in $C$. capixaba is longer than in $C$. carvalhoi and $C$. atlantica (Table 2). The dominant frequency corresponds to the fundamental frequency in all three species (Figures 2 and 4). 
Wogel et al.

Table 1 - Measurements (mm) of the 11 tadpoles of Chiasmocleis carvalhoi at Stage 35 of Gosner (1960).

\begin{tabular}{lcc}
\hline CHARACTER & MEAN \pm SD & RANGE \\
\hline Total length & $16.60 \pm 0.50$ & $15.50-17.20$ \\
Body length & $5.80 \pm 0.10$ & $5.60-6.00$ \\
Body height & $3.30 \pm 0.10$ & $3.10-3.50$ \\
Body width & $4.00 \pm 0.10$ & $3.80-4.20$ \\
Tail length & $10.80 \pm 0.50$ & $9.70-11.30$ \\
Tail height & $3.70 \pm 0.10$ & $3.40-3.90$ \\
Tail musculature height & $1.40 \pm 0.10$ & $1.30-1.50$ \\
Dorsal fin height & $1.32 \pm 0.07$ & $1.20-1.44$ \\
Ventral fin height & $1.48 \pm 0.05$ & $1.44-1.60$ \\
Eye diameter & $0.84 \pm 0.04$ & $0.80-0.88$ \\
Interorbital distance & $2.90 \pm 0.10$ & $2.70-3.00$ \\
Snout-eye distance & $1.60 \pm 0.10$ & $1.40-1.80$ \\
Oral disc & $1.51 \pm 0.04$ & $1.45-1.55$ \\
\hline
\end{tabular}

Table 2 - Summary of acoustic parameters of the vocalizations of Chiasmocleis atlantica, Chiasmocleis capixaba, and Chiasmocleis carvalhoi. Values are presented as mean $\pm \mathrm{SD}$, [range], (N).

\begin{tabular}{|c|c|c|c|}
\hline CHARACTERISTICS & $\begin{array}{c}\text { Chiasmocleis } \\
\text { atlantica }\end{array}$ & $\begin{array}{c}\text { Chiasmocleis } \\
\text { capixaba }\end{array}$ & $\begin{array}{c}\text { Chiasmocleis } \\
\text { carvalhoi }\end{array}$ \\
\hline Call duration (ms) & $\begin{array}{c}137 \pm 22 \\
{[64-186]} \\
(128)\end{array}$ & $\begin{array}{c}52 \pm 5 \\
{[47-61]} \\
(39)\end{array}$ & $\begin{array}{c}48 \pm 5 \\
{[42-54]} \\
(40)\end{array}$ \\
\hline Interval between notes (ms) & $\begin{array}{c}28 \pm 5 \\
{[23-47]} \\
(126)\end{array}$ & $\begin{array}{c}59 \pm 7 \\
{[54-86]} \\
(34)\end{array}$ & $\begin{array}{c}37 \pm 1 \\
{[34-43]} \\
(36)\end{array}$ \\
\hline Number of pulses & $\begin{array}{c}16.7 \pm 2.1 \\
{[7-22]} \\
(316)\end{array}$ & $\begin{array}{c}8.7 \pm 0.8 \\
{[8-10]} \\
(39)\end{array}$ & $\begin{array}{c}9.3 \pm 0.9 \\
{[8-10]} \\
(69)\end{array}$ \\
\hline Pulse duration (ms) & $\begin{array}{c}5 \pm 0.5 \\
{[4-6]} \\
(69)\end{array}$ & $\begin{array}{c}4 \pm 0.3 \\
{[3-4]} \\
(50)\end{array}$ & $\begin{array}{c}3 \\
{[3]} \\
(11)\end{array}$ \\
\hline Interval between pulses (ms) & $\begin{array}{c}4 \pm 0.6 \\
{[3-6]} \\
(60)\end{array}$ & $\begin{array}{c}3 \pm 0.5 \\
{[2-3]} \\
(50)\end{array}$ & $\begin{array}{c}2 \pm 0.4 \\
{[2-3]} \\
(11)\end{array}$ \\
\hline Dominant frequency $(\mathrm{kHz})$ & $\begin{array}{c}3.54 \pm 0.11 \\
{[3.32-3.75]} \\
(125)\end{array}$ & $\begin{array}{c}4.75 \pm 0.06 \\
{[4.61-4.87]} \\
(38)\end{array}$ & $\begin{array}{c}4.84 \pm 0.07 \\
{[4.69-4.96]} \\
(21)\end{array}$ \\
\hline
\end{tabular}



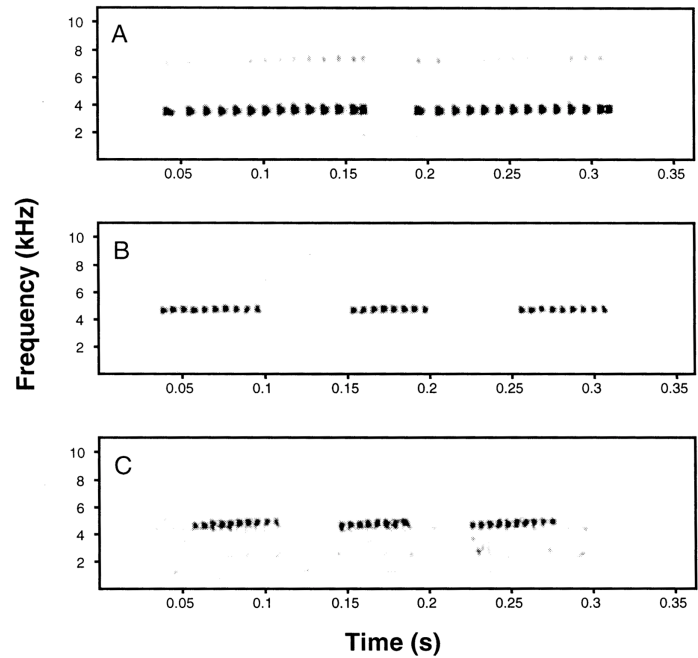

Figure 2 - Sonograms of advertisement calls of (A) Chiasmocleis atlantica (with two pulsed notes), air temperature of $23^{\circ} \mathrm{C}$, (B) Chiasmocleis capixaba (with three pulsed notes), air temperature of $20^{\circ} \mathrm{C}$, and (C) Chiasmocleis carvalhoi (with three pulsed notes), air temperature of $23^{\circ} \mathrm{C}$.

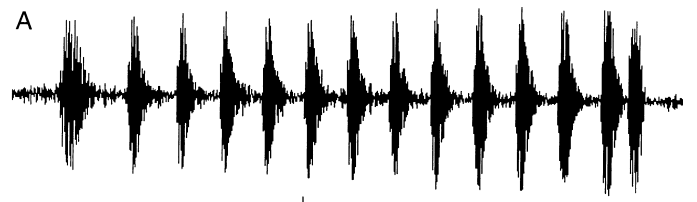

B
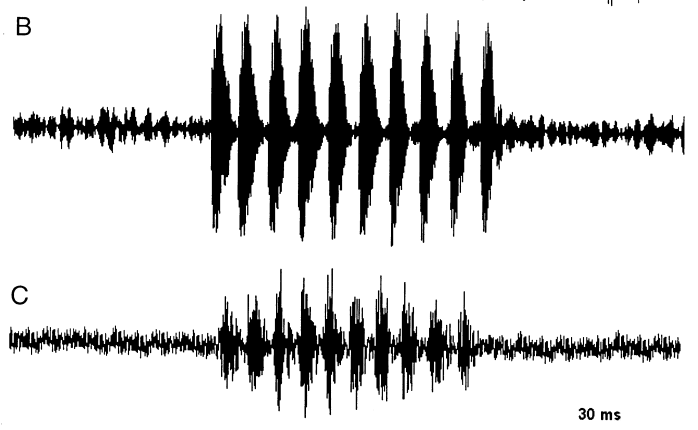

Figure 3 - Waveforms showing one pulsed note of advertisement call of (A) Chiasmocleis atlantica, (B) Chiasmocleis capixaba, and (C) Chiasmocleis carvalhoi.
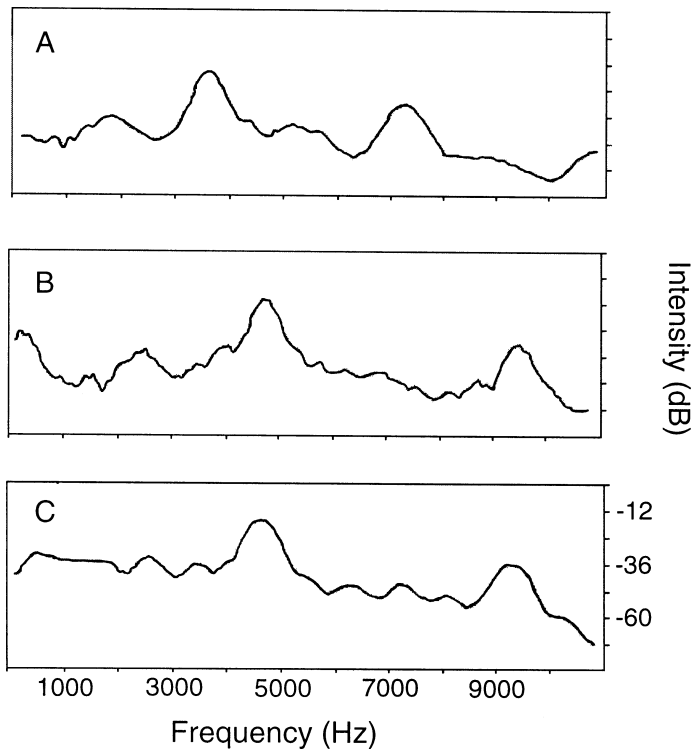

Figure 4 - Frequency spectrum, along the $\mathrm{X}$-axis, and amplitude, in $\mathrm{dB}$, along the $\mathrm{Y}$-axis, of advertisement calls of (A) Chiasmocleis atlantica, (B) Chiasmocleis capixaba, and (C) Chiasmocleis carvalhoi.

The numbers of pulses in these three species are positively correlated with time (Figure 5). Chiasmocleis atlantica has the most accentuated increase in the number of pulses as the male calls (Pearson coefficient correlation; $r=0.81$, 0.55 , and $0.64 ; p=0.001, C$. atlantica, $C$. capixaba, and C. carvalhoi, respectively).

Males were observed calling above or within leaf litter around temporary ponds after heavy rains, mainly in October 2001 ( $C$. capixaba) and in November 2002 (C. atlantica and $C$. carvalhoi). The latter two species are syntopic and their reproductive activities overlap. Breeding aggregations of $C$. atlantica and $C$. carvalhoi were observed on only six nights $(11,12$, and 13 November 2002, 10 December 2002, 14 January 2003, and 19 March 2003). A bout of calling activity on 12 November 2002 of these two species lasted eight hours, starting at 18:00 $\mathrm{h}$ and finishing at 
02:00 h. We observed reproductive aggregations of Chiasmocleis capixaba only in temporary ponds, but never around the lake (a permanent body of water in which several other anuran species were observed) located about $50 \mathrm{~m}$ from the temporary pools.
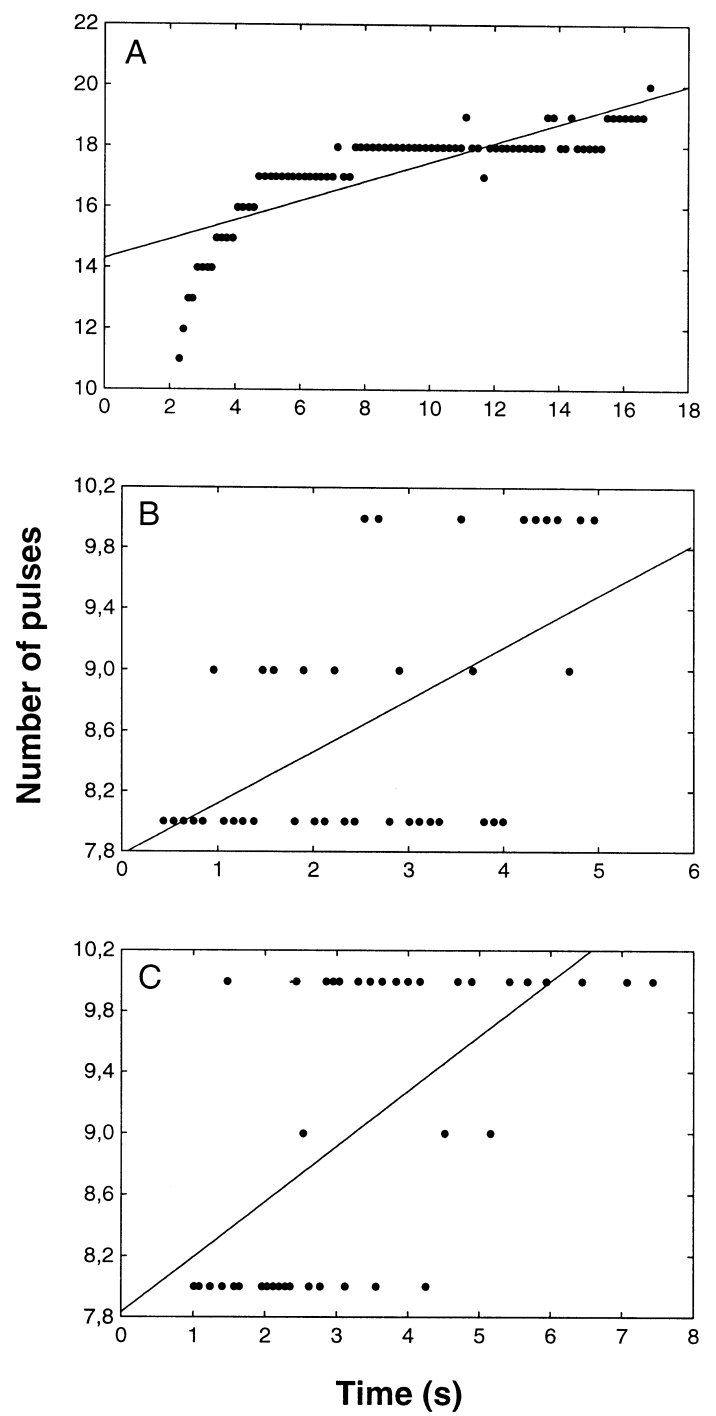

Figure 5 - Correlations between the number of pulses and time of vocalizations of (A) Chiasmocleis atlantica, (B) Chiasmocleis capixaba, and (C) Chiasmocleis carvalhoi (for all Pearson correlations $P=0.001)$.
The dendrogram obtained from the cluster analysis of the acoustic parameters reveals that the species of Chiasmocleis that occur in the Atlantic Rainforest comprise two assemblies (Figure 6). One group, composed of $C$. atlantica, C. leucosticta, and C. schubarti, includes species of medium size (body size range from 19.0-26.3 $\mathrm{mm}$ in males; Cruz et al. 1997) that have longer calls with lower dominant frequencies. Chiasmocleis capixaba and $C$. carvalhoi constitute the other group; these species are smaller (body size range from 14.7-18.3 mm in males; Cruz et al. 1997) and have shorter calls with higher dominant frequencies.

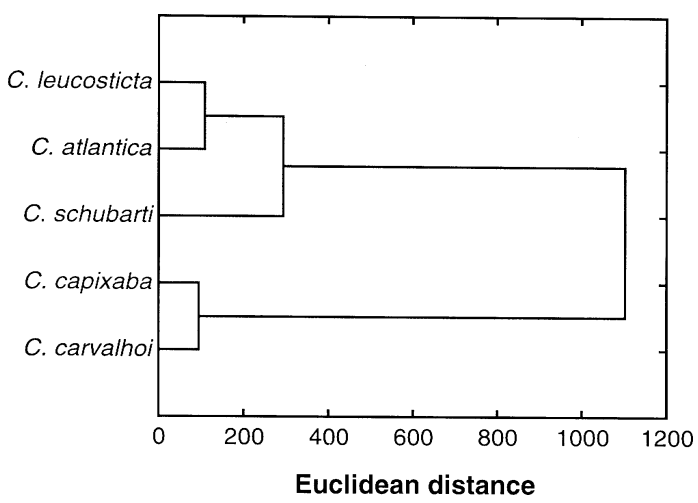

Figure 6 - Cluster analysis (Euclidean distance) among acoustic parameters (call duration and dominant frequency) of advertisement calls of species of the genus Chiasmocleis from Atlantic Rainforest.

\section{Discussion}

The tadpole of Chiasmocleis carvalhoi is similar in coloration and general aspect to the tadpole of $C$. ventrimaculata described and illustrated in Schlüter and Salas (1991). However, the dorsal fin of $C$. carvalhoi originate at the end of the body and is approximately straight for the firsts two thirds of its length, whereas in C. ventrimaculata the dorsal fin originates close to tail musculature 
and rise in its two thirds of tail. Furthermore, the height of the tail musculature of $C$. carvalhoi is less than that of $C$. ventrimaculata (Schlüter and Salas 1991).

The advertisement call of Chiasmocleis carvalhoi described by Hartmann et al. (2002) is structurally similar to the one described here, with the exception of the harmonic structure and distinctness of pulses. Differences in some acoustic parameters (e.g., call duration and interval between calls) measured here and in Hartmann et al. (2002) resulted from differentiated analysis: in our study each pulsed note was considered a call, while in their study a call corresponded to a series of pulsed notes. Thus, as analyzed herein, call duration did not vary and interval between calls was conservative.

Our study corroborates the monophyly of the genus Chiasmocleis proposed by Hartmann et al. (2002) based on similarities in advertisement calls. Pulsed calls could represent a synapomorphy for this group, even if polarity of this character and vocalizations of the closely related genera (as proposed by Wild 1995, Hartmann et al. 2002) are unknown.

Reproductive aggregations of Chiasmocleis capixaba were observed only in temporary ponds, never in the nearby permanent body of water. A similar behavior was also observed in Chiasmocleis shudikarensis (Zimmerman and Bogart 1988). The "Chiasmocleis rain pools" (as defined by these authors) were exclusively pools on the forest floor and never semipermanent forest pools or puddles besides streams, which were less ephemeral and more frequently filled. A bout of calling activity on 4 November 2001 of $C$. capixaba lasted eight hours, starting at 19:00 $\mathrm{h}$ and finishing at 03:00 h.

The species groups emerging from the cluster analysis seem to reflect the correlation between body size and the acoustic properties of the calls, in which call duration and dominant frequency are positively and negatively correlated with body size, respectively (Zweifel
1968, Zimmerman 1983, Sullivan and Wagner 1988, Giacoma et al. 1997). Moreover, in the syntopic species $-C$. atlantica and $C$. capixaba in Reserva Biológica União, RJ, and C. capixaba and C. schubarti in Reserva Biológica de Duas Bocas, ES - the members of species pairs possess distinct advertisement calls. This observation agrees with Duellman and Pyles' (1983) findings, in which calls of closely related, sympatric species tend to be less similar than those of closely related allopatric species.

\section{Acknowledgments}

We thank José P. Pombal Jr., Linda Trueb, Luiz N. Weber, Paulo Passos, and Ronaldo Fernandes for helpful comments on the manuscript, and are indebted to Paulo R. Nascimento for the illustrations of larvae. We are grateful to the Coordenação de Aperfeiçoamento de Pessoal de Nível Superior (CAPES), Conselho Nacional de Desenvolvimento Científico e Tecnológico (CNPq, proc. 479663/01-7), and Fundação Universitária José Bonifácio (FUJB) for financial support, and to the Instituto Brasileiro do Meio Ambiente (IBAMA) for the permit to study anurans at the Reserva Biológica União (license number 210/ 2003-IBAMA) and Reserva Biológica de Duas Bocas (license number 010/2001-RAN/ IBAMA).

\section{References}

Altig, R. 1970. A key to the tadpoles of the continental United States and Canada. Herpetologica 26: 180 207.

Altig, R. and R. W. McDiarmid. 1999. Body plan. Development and morphology. Pp. 24-51 in R. W. McDiarmid and R. Altig (eds.), Tadpoles - the biology of anuran larvae. Chicago and London. The University of Chicago Press.

Caramaschi, U. and C. A. G. Cruz. 2001. A new species of Chiasmocleis Mehély, 1904 from Brazilian Amazonia (Amphibia, Anura, Microhylidae). Boletim do Museu Nacional, Nova Série 469: 1-8. 
Wogel et al.

Caramaschi, U. and B. V. S. Pimenta. 2003. Duas novas espécies de Chiasmocleis Méhelÿ, 1904 da Mata Atlântica do sul da Bahia, Brasil (Amphibia, Anura, Microhylidae). Arquivos do Museu Nacional 61: 195202.

Cruz, C. A. G., U. Caramaschi and E. Izecksohn. 1997. The genus Chiasmocleis Mehély, 1904 (Anura, Microhylidae) in the Atlantic Rain Forest of Brazil, with description of three new species. Alytes 15: 4971 .

Duellman, W. E. and R. A. Pyles. 1983. Acoustic resource partitioning in anuran communities. Copeia 1983: 639-649.

Duellman, W. E. and L. Trueb. 1986. Biology of Amphibians. New York. McGraw-Hill. 670 pp.

Frost, D. R. 2003. Amphibian Species of the World - an online reference. URL: http://research.amnh.org/ herpetology/amphibia/index.html. Captured on 15 December 2003

Giacoma, C., C. Zugolaro and L. Beani. 1997. The advertisement calls of the green toad (Bufo viridis): variability and role in mate choice. Herpetologica 53: 454-464.

Gosner, K. L. 1960. A simplified table for staging anuran embryos and larvae with notes on identification. Herpetologica 16: 183-190.

Hartmann, M. T., P. A. Hartmann and C. F. B. Haddad. 2002. Advertisement calls of Chiasmocleis carvalhoi, Chiasmocleis mehelyi, and Myersiella microps (Microhylidae). Journal of Herpetology 36: 509-511.
Hero, J. M. 1990. An illustrated key to tadpoles occurring in the Central Amazon rainforest, Manaus, Amazonas, Brasil. Amazoniana 11: 201-262.

Mainly, B. F. J. 2000. Multivariate Statistical Methods a primer. Boca Raton. Chapman and Hall/CRC. 215 pp.

Nelson, C. E. 1973. Mating calls of the Microhylinae: descriptions and phylogenetic and ecological considerations. Herpetologica 29: 163-176.

Schlüter, A. and A. W. Salas. 1991. Reproduction, tadpoles, and ecological aspects of three syntopic microhylid species from Peru (Amphibia: Microhylidae). Stuttgarter Beiträge zur Naturkunde, Serie A (Biologie) 458: 1-17.

Sullivan, B. K. and W. E. Wagner, Jr. 1988. Variation in advertisement and release calls, and social influences on calling behavior in the gulf coast toad (Bufo valliceps). Copeia 1988: 1014-1020.

Wild, E. R. 1995. New genus and species of Amazonian microhylid frog with a phylogenetic analysis of the new world genera. Copeia 1995: 837-849.

Zimmerman, B. L. 1983. A comparison of structural features of calls of open and forest habitat species in the Central Amazon. Herpetologica 39: 235-246.

Zimmerman, B. L. and J. P. Bogart. 1988. Ecology and calls of four species of Amazonian forest frogs. Journal of Herpetology 22: 97-108.

Zweifel, R. G. 1968. Effects of temperature, body size, and hybridization on mating calls of toads, Bufo $a$. americanus and Bufo woodhousii fowleri. Copeia 1968: 269-285. 